\title{
Opportunities \& Challenges Involved in Local Fabric Sourcing Strategy: A Case Study of Epic Group in Bangladesh
}

\author{
Sirajum Munir, Bangladesh University of Textiles \\ Md. Rafiqul Islam Rana, University of Missouri, USA
}

Keywords: Bangladesh, textile industry, woven fabric, local sourcing, case study

The globalization phenomenon has induced a considerable change in manufacturing and supply chain strategies across the apparel and fashion value chain. To get cost-benefit, fashion retailer, and manufacturers prefers relocation of their operations to overseas, and the sourcing of components from, low-labor cost countries (Barnes \& Lea-Greenwood, 2006). Sourcing is defined as the process of determining how and from where manufactured goods or components will be procured (Ha-Brookshire, 2015). The main motivational force to do sourcing of garments/fabrics is to give the highest level of satisfaction, at low production cost. However, in recent years, in order to cope with the ever-changing demand driven by the volatile fashion industry trend in the market, local sourcing practice has been getting significant momentum. With reduced lead time, local sourcing helps to match market demand and supply better (Choi, 2013). Bangladesh has placed itself as the second largest exporter of readymade garments; however, a lion share of raw materials such as fabrics, trims, accessories for apparel production are being imported from other countries such as China, Turkey, and India (Islam \& Liang, 2012). Therefore, the goal of this research is to investigate the challenges of local fabric sourcing in the Epic Group of Bangladesh and identify the scope of improvement.

The cluster-based theory of firm was used to achieve the research goal. Porter $(2011, p .199)$ defined cluster as "a geographically proximate group of interconnected companies and associated institutions in a particular field, linked by commonalities and complementaries." If firms within a cluster have better access to suppliers rooted in the same system compared to their international competitors, and these suppliers are strategically relevant for the buyer's competitiveness, cluster-based firms can accrue competitive advantages (Steinle \& Schiele, 2008). This has implications for sourcing decisions, since engaging in collaborative development or building a supplier network, rather than relying on dyadic relationships, is favored by geographical and cultural proximity. Local sourcing typically denotes the sourcing, purchasing, or procurement products from within a specific radius (distance) from where they will be used or sourced, or from a given geographical area (Choi, 2013). For garment production, fabric and trims are the raw material that needs to be outsourced. Not only does the fabric have to be appropriate and suited to the garment design and end use, but it must also be made available at the precise time when it is needed. The process of fabric sourcing is very dynamic; it changes with the fabric type, cost quoted by fabric supplier, lead time, buyers requirement (Islam \& Liang, 2012). Therefore, it is crucial to identify the challenges and scopes of local fabric souring

Page 1 of 4

(c) 2020 The author(s). Published under a Creative Commons Attribution License

(https://creativecommons.org/licenses/by/4.0/), which permits unrestricted use, distribution, and reproduction in any medium, provided the original work is properly cited.

ITAA Proceedings, \#77 - https: //itaaonline.org 
so that the local fabric manufacturing firms in Bangladesh act upon them accordingly and build their clustered competitive advantage.

To investigate the research agenda, a case study of Epic Group in Bangladesh was conducted. A case study on local fabric sourcing practices offered to look into the complex links and underlying implications (Yin, 2011). Established in 1971 and headquartered in Hong Kong, Epic is a multinational textile company with world class manufacturing facilities in Asia, employing over 20,000 people. Epic maintains design studios in Hong Kong and London and garment production factories in Bangladesh, Vietnam, Jordan \& Ethiopia. In this study, preliminary data was collected through firsthand visit to their sourcing unit located in Dhaka, Bangladesh. Primary qualitative data was collected through one on one interviews and close ended questionnaires. Secondary data was collected from the company website and annual reports.

The study revealed the below factors affecting local fabric sourcing in Bangladesh:

Table 1: Challenges in local fabric sourcing for Bangladeshi fabric mills.

Technical Limitation: The majority of Bangladeshi local textile mills are producing basic composition fabrics i.e., 100\% Cotton/Cotton Stretch items. Hardly, 10-15 mills are producing different synthetic and blended items since the last five years only. So, in terms of manufacturing technology, Bangladesh has vast room to improve.

Lack of Technical Experts: In many Bangladeshi mills, there are huge numbers of foreign nationals working in the production department. Especially in the product processing and development area. This is because of the unavailability of local experts. Although many local textile graduates are serving in different departments of textile mills, a large number of foreigners have occupied most of the middle to top level management positions.

Weak Research and Development (R\&D): In Bangladesh, there is nothing called R\&D. Here most of the R\&D departments are doing product replication, which is provided by the buyers. So, research-based product innovation should be emphasized in mill level and newer qualities, designs should be offered in each season.

Failure to Meet Commitment: In many cases, local fabric mills are running with large order volumes that are more than its capacity and unable to perform at a satisfactory level. To meet buyer's demand in terms of fabric quality and lead time, local mills struggle significantly.

Lack of Raw Material: Raw material unavailability is one of the top disadvantages of Bangladeshi fabric mills. As local mills source fiber, especially cotton from foreign countries, fiber purchase related planning, pricing, lead time, inventory management related tasks are difficult to perform efficiently with the buyers.

Limited Number of Export Oriented Mills: At present, Bangladesh has more than 802 weaving factories \& almost 244 processing mills. However, a lack of vertical set up is a limitation for local fabric mills to meet the international buyer's requirement. The number of mills having

Page 2 of 4

(c) 2020 The author(s). Published under a Creative Commons Attribution License (https://creativecommons.org/licenses/by/4.0/), which permits unrestricted use, distribution, and reproduction in any medium, provided the original work is properly cited.

ITAA Proceedings, \#77 - https://itaaonline.org 
both weaving \& processing set up is fewer considering denim, non-denim \& home textile products. Therefore, local mills cannot perform against large order volumes.

Communication Skills: Most of the Bangladeshi mills could not reach a satisfactory level when it comes to communication. Foreign mills are very clear in terms of expectations and understanding of customers compared to the local mills.

This study showed the actual scenario of local fabric sourcing in Bangladesh for the first time. The importance of local sourcing is increasing day by day as the product life cycles are getting short, lead times are getting narrow, and imposing of tariffs makes it difficult to get competitive pricing. Bangladesh, as a global hub for apparel production, should take necessary steps to promote local sourcing and strengthen its competitive advantage. Adopting modern technology and machinery, proper technical training of local talents, securing raw materials from the local market and developing a strong inventory management system, establishing a strong R\&D team for product diversification, developing strong communication skills, and transparency with buyers are of utmost importance. Future research could be done on identifying process specific gaps in terms of production planning, control, and management and provide Bangladeshi industry leaders with corrective measures and how to act upon them.

Page 3 of 4

(c) 2020 The author(s). Published under a Creative Commons Attribution License (https://creativecommons.org/licenses/by/4.0/), which permits unrestricted use, distribution, and reproduction in any medium, provided the original work is properly cited.

ITAA Proceedings, \#77 - https://itaaonline.org 


\section{References}

Barnes, L., \& Lea-Greenwood, G. (2006). Fast fashioning the supply chain: shaping the research agenda. Journal of Fashion Marketing and Management: An International Journal.

Choi, T. M. (2013). Local sourcing and fashion quick response system: The impacts of carbon footprint tax. Transportation Research Part E: Logistics and Transportation Review, 55, 43-54.

Ha-Brookshire, J. (2015). Global sourcing: New research and education agendas for apparel design and merchandising. Fashion and Textiles, 2(1), 15.

Islam, M. S., \& Liang, G. Q. (2012). Supply chain management on apparel order process: A case study in Bangladesh garment industry. Asian Journal of Business and Management Sciences, 2(8), 60-72.

Patti, A. L. (2006). Economic clusters and the supply chain: a case study. Supply Chain Management: An International Journal.

Porter, M. E. (2011). Competitive advantage of nations: creating and sustaining superior performance.

Steinle, C., \& Schiele, H. (2008). Limits to global sourcing?: Strategic consequences of dependency on international suppliers: Cluster theory, resource-based view and case studies. Journal of purchasing and supply management, 14(1), 3-14.

Yin, R. K. (2011). Applications of case study research. sage. 